\title{
A new species of Lepidaploa (Vernonieae - Asteraceae) from Southeastern Brazil
}

\author{
Uma nova espécie de Lepidaploa \\ (Vernonieae - Asteraceae) do Sudeste do Brasil
}

\author{
Aristônio M. Teles $^{1}$, Marcos Sobral ${ }^{2}$ \& Jimi N. Nakajima ${ }^{3}$
}

\begin{abstract}
Lepidaploa opposita, a new species from the Atlantic Forest in southeastern Brazil, is described and illustrated. The new species is readily distinguished from other Lepidaploa species by the opposite leaves. This character is very unusual in this genus, as well as in subtribe Lepidaploinae and tribe Vernonieae.

Key words: Atlantic Forest, Compositae, Lepidaploinae, taxonomy.

Resumo

Lepidaploa opposita, uma nova espécie da Mata Atlântica no sudeste brasileiro, é descrita e ilustrada. A nova espécie distingue-se das demais do gênero pelas folhas opostas. Essa característica é incomum no gênero, bem como na subtribo Lepidaploinae e tribo Vernonieae.

Palavras-chave: Floresta Atlântica, Compositae, Lepidaploinae, taxonomia.
\end{abstract}

\section{Introduction}

The genus Lepidaploa (Cass.) Cass. (subtribe Lepidaploinae, tribe Vernonieae; Keeley \& Robinson 2009) was reestablished as a genus segregate from the broad concept of Vernonia by Robinson (1990). This genus comprises about 142 species and it is widely distributed from Mexico and the Antilles through Brazil and Argentina (Robinson 1999).

Lepidaploa can be recognized by the alternate leaves; scorpioid-cymose or seriatecymose coflorescences; heads sessile; involucre wide campanulate, involucral bracts fewer that 100, 3-6 seriate, imbricate; receptacle plane to convex; florets perfect, 8-35; corolla narrowly funnel-shaped; anthers with appendages, these rarely glandulose, the base sagittate; style with acute trichomes; cypselae prismatic; pappus biseriate, outer series short and the internal series of capillary bristles; pollen type C, D or G (Robinson 1990).

Along the examination of specimens of Asteraceae from the southeastern Brazilian State of Espírito Santo, we have found a very distinctive species of Lepidaploa with opposite leaves, that we considered as new and describe it herein.

\section{Materials and Methods}

This work was based on the analysis of collections that are housed at BHCB and MBML herbaria. Leaves, heads and florets were measured with the use of pachymeter. Florets were diafanized in sodium hydroxide $5 \%(\mathrm{NaOH})$ solution and the drawings were made with the help of a microscope with drawing tube. Taxonomic species concept was according to Assis \& Brigandt (2009) and Stuessy (1990), which define a natural kind by an exclusive feature or a combination of them. The circumscription of the species was complemented by geographic distribution and habitat. The classification of the vegetation was according to Oliveira-Filho \& Fontes (2000) and Barthlott et al. (1993).

\section{Results and Discussion}

Lepidaploa opposita A.Teles, Sobral \& J.N.Nakaj, sp. nov. Type:BRAZIL. ESPÍRITOSANTO: São Roque de Canaã, Alto Misterioso, afloramento rochoso com vegetação rupestre, inselberg, 1.VIII.2004, fl. e fr., A.P. Fontana, F. Fadini, L. Lima \& M. Araújo 894 (holotype MBML!; isotype BHCB!). Fig. 1

Species haec ab omnibus congeneribus foliis oppositis, laminis sagittiferis basis cordatisque recedit. 


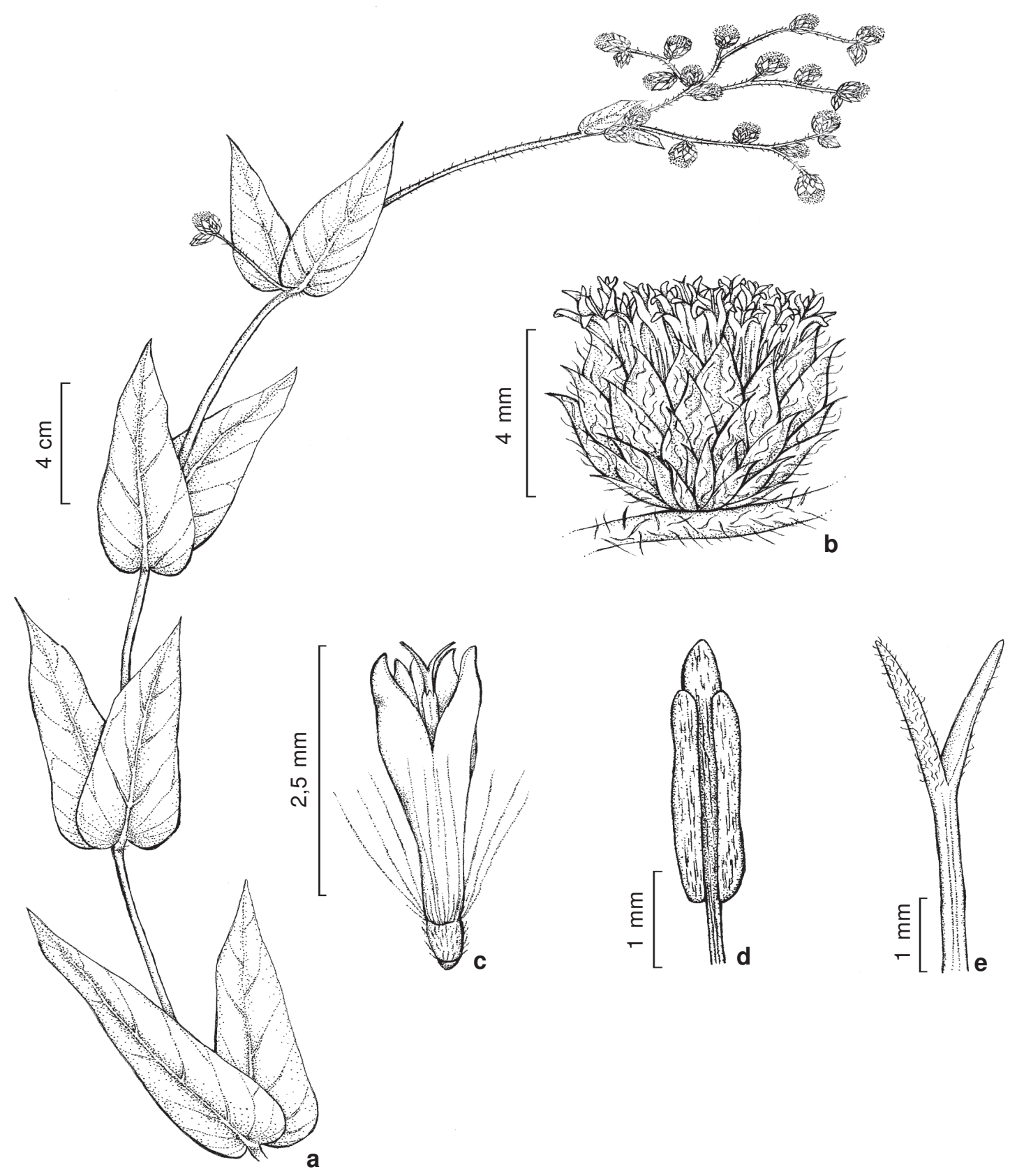

Figure 1 - Lepidaploa opposita A.Teles, Sobral \& J.N.Nakaj - a. flowering branchlet; b. capitula; c. floret; d. stamen; e. style. (Lombardi 1296). 
Subshrub to shrub, perennial, ca. $1.6 \mathrm{~m}$ high. Stem flexible, multisulcate, reddish in the base and greenish in the apex, the nodes hirsute. Leaves 1.5$6 \times 0.5-2 \mathrm{~cm}$, opposite, sagittiform, coriaceous, the adaxial face with sparsely simple trichomes and glandular sessile trichomes, the abaxial face with sparsely simple tector trichomes, venation penninervate with 4 to 8 secondary veins prominent abaxially; apex acute; base cordate; margins entire, revolute; petioles $2-3 \mathrm{~mm}$ long. Heads homogamous, discoid and sessile, arranged in scorpioid cymes, branches of the capitulescences hirsute. Involucre 3-5 $\times 2-4 \mathrm{~mm}$; phyllaries in 5-6 graduated series, lanceolate, greenish, apex acute, brownish, the external ones with ca. $2 \mathrm{~mm}$ long, the internal ones with ca. $5 \mathrm{~mm}$ long, hirsute; receptacle plane, deeply alveolate, epaleaceous. Florets perfect, ca. 20 in a head; corolla tubulose, whitish, tube $2-3 \mathrm{~mm}$ long, deeply 5-laciniate, laciniae $2.5-3 \mathrm{~mm}$ long; anthers $1.7-2 \mathrm{~mm}$ long, the apical appendage triangular, exserted; style 5.5-6 mm long, branches ca. $2 \mathrm{~mm}$ long. Cypselae ca. $1 \mathrm{~mm}$ long, obconical, pilose; pappus bristles numerous, the outer row with short scales $0.5-0.6 \mathrm{~mm}$ long, the inner row with scabridbarbellate bristles $3.5-4 \mathrm{~mm}$ long.

Material examined: BRAZIL. ESPÍRITO SANTO: Santa Teresa, Estação Biológica da Santa Lúcia, 19.VII.1984, W. Boone 264 (MBML); Fundão Goiapaba-Açú, 15.VII.1998, fl. e fr., L. Kollmann et al. 244 (MBML). MINAS GERAIS: Marliéria, Parque Estadual do Rio Doce, 16.VII.1996, fl. e fr., J.A. Lombardi 1296 (BHCB). RIO DE JANEIRO: Nova Friburgo, Macaé de Cima, 19.IV.1989, fl. e fr., H.Q.B. Fernandes et al. 2738 (MBML).

The epithet is allusive to the opposite leaves, an unusual character in the genus.

The species is known to the Brazilian states of Espírito Santo, in the municipalities of Santa Teresa and São Roque de Canaã, Minas Gerais, in the municipality of Marliéria, and Rio de Janeiro, in the municipality of Nova Friburgo, growing on rocky soils between 800 to 1450 meters above sea level, associated with litholic vegetation at "Inselbergen" (Barthlott et al. 1993).

Specimens with flowers and fruits were collected from May to October.

This new species is easily recognized by the opposite leaves, an unusual character in Lepidaploa and until now unrecorded for the Brazilian species. Keeley \& Robinson (2009) cite that the opposite leaves are unusual in subtribe Lepidaploinae, to which
Lepidaploa belongs, occurring in one Jamaican species (Lepidaploa verticillata), and one Colombian variety of another species (Lepidaploa canescens var. opposita H.Rob.) (Robinson 1999), and one Peruvian species of Trepadonia (Robinson 2000), another genus segregated from Vernonia s.l. by Robinson (1994). Lepidaploa opposita differs from these two Lepidaploa species by leaves sagittiform with cordate base. Trepadonia oppositifolia resembles this new species, however it is scandent, with ovate and petiolate leaves (versus shrub, with sessile, sagittiform leaves with cordate base), and presents a pollen type distinct from those occurring in Lepidaploa, thus belonging to subtribe Vernoniinae.

\section{Acknowledgments}

We are grateful to Vinícius Yano Corrêa for the line drawings.

\section{References}

Assis, L.C.S. \& Brigandt, I. 2009. Homology: homeostatic property cluster kinds in systematics and evolution. Evolutionary Biology: 36: 248-255.

Barthlott, W.; Gröger, A. \& Porembski, S. 1993. Some remarks on the vegetation of tropical Inselbergs: diversity and ecological differentiation. Biogeographica 69: 105-124.

Keeley, S.C. \& Robinson, H. 2009. Vernonieae. In: Funk, V.A.; Suzanna, A.; Stuessy, T.F. \& Bayer, R.J. (eds.). Systematics, evolution, and biogeography of Compositae. IAPT, Vienna. Pp. 439-470.

Oliveira-Filho, A.T. \& Fontes, M.A.L. 2000. Patterns of floristic differentiation among Atlantic forests in southeastern of Brazil and the influence of climate. Biotropica 32: 793-810.

Robinson, H. 1990. Studies in the Lepidaploa complex (Vernonieae: Asteraceae) VII. The genus Lepidaploa. Proceedings of Biologial Society of Washington 103: 464-498.

Robinson, H. 1994. Cololobus, Pseudopiptocarpha, and Trepadonia, three new genera from South America (Vernonieae: Asteraceae). Proceedings of Biological Society of Washington 107: 557-568.

Robinson, H. 1999. Generic and subtribal classification of American Vernonieae. Smithsonian Contributions to Botany 89: 1-116.

Robinson, H. 2000. A new species of Trepadonia (Asteraceae: Vernonieae) from Peru. Sida, Contributions to Botany 19: 111-113.

Stuessy, T.F. 1990. Plant taxonomy, the systematic evaluation of comparative data. Columbia University Press, New York. 514p. 